\title{
A Study on the Cohabitation of Minor as Husband and Wife Affecting the Quality of Life
}

\author{
Kamonwan Yoowattana
}

\begin{abstract}
According to the law of Thailand, a marriage can be a completedmarriage when the man and woman have reached the age of seventeen years old. But, if there are any appropriate reasons, the court may allow a couple to marry before reaching such age. Therefore, minors who have their ages up to the criteria set by law, they can enter into marriage with the consent of parents, just father or mother, adopter, or guardian depending on each case. The marriage by law will allow minors to become sui juris. However, if minors enter into marriage without permission, the marriage is counted as voidable. In this case, if the court has seen that there is an appropriate reason, minors may be allowed to marry under the age of seventeen. If the applicant is a person under the age of eighteen who has had sexual intercourse on child over the thirteen years old, but not exceeds fifteen years old with assent, the offender will not be punished, and he will be exempted from being minor as per Civil Law. It can be said that the conditions of marriage related to age and consent of minors are not strict. If it is a voidable marriage, and the cancellation of the marriage has not been ordered by the court until man and woman attain the age of seventeen or twenty, or if the woman is pregnant, the marriage is counted as valid from the time it was made.
\end{abstract}

Index Terms-Marriage, minor, law, wife.

\section{INTRODUCTION}

The relationship within family is the relationship that starts with the connection of need to stay together to create lineage and support each other. The cohabitation as husband and wife in each country has similar forms and methods, but it will have some differences in terms of family creating conditions such as the need of registration. On the other hand, some countries will provide protection on the registration for marriage, registration for relationship, and cohabitation agreement. Thus, such protection is performed according to the culture and tradition of each nation. Moreover, some countries apply the regulations as per religious tradition to link to the practice for the completion of the marriage. Mostly, both husband and wife were born and raised in different background so that they possess unique idea and value [1], [2].

According to the Civil and Commercial Code of Thailand, Section 1457, marriage under this Code shall be affected only on registration being made. Therefore, if man and woman have intention of cohabitation as husband and wife without entering into marriage registration, it is not

Manuscript received June 23, 2016; revised August 22, 2016. This work was supported in part by the research and development institute, Suan Sunandha Rajabhat University, Thailand.

Kamonwan Yoowattana is with Faculty of Humanity and Social Science, SuanSunandhaRajabhat University, Bangkok, Thailand (e-mail: kamonwan.na@ssru.ac.th,nook_toto@hotmail.com) considered as marriage. The conditions of marriage is provided in Chapter 5of Civil and Commercial Code with several criteria such as age of spouse, ability of spouse who is not considered as being insane or incompetent, not a direct-blood relative, not siblings of the same parents nor siblings of the same mother or father, not a marriage between adopter and foster, not a person who is already a spouse of another person, and the marriage shall be made with mutual consent and it shall be the marriage by law which causes the relationship between husband and wife as well as rights and duties to each other.

However, a marriage that is contrary to the terms of the law may be void or voidable depending on each case. According to law, the marriage can be made between man and woman at seventeen years of age can enter into marriage, but with a reasonable ground, the court may permit them to be married before. It can be seen from Section 1448 that the marriage as per the law of Thailand is made only between males and females. The law does not allow persons of the same sex to get married. Thus, it is because the law is based on gender of person from birth without considering about the transsexual. Other than the gender of individual, the age of individual is in the conditions of marriage as well. In this case, males and females at seventeen years of age can enter into marriage, but with a reasonable ground, the court may permit them to be married before. The court may allow a person under the age of seventeen years old to get married if it is deemed necessary for the advantages of spouses without considering a minimum age of men and women as it is made by the discretion of the court [3].

In each year, the National Bureau of Statistics has finalized the overall population by age to categorize as per marital status such as single, widowed, divorced and separated, including unknown status. It can be considered from the statistics of the population at the age of 13 years old or above separated as per marital status, group of age, gender, and administration area. From the statistic obtained from $55,380,017$ people over the age of 13 years old or above who are separated by marital status, group of age, gender, and administration area, it is found that there are 15,620 married, 695 widowed, 244 divorced, and 264 separated for people at the age of 13 14-years. For people at the age of 19-15 years old, there are 380,558 married, 5, 325 widowed, 3, 942 divorced, and 19, 920 separated, including the marriage between people who do not reach the age of 20 year old for 396, 178 people, 6, 020 widowed, 4, 186 divorced, and 20,184 separated. There are $4,370,857$ people with the age of 44-40 years old entered in to marriage, and this is counted as the maximum numbers of marriage.

The Bureau of Reproductive Health has compiled statistics of birth rates in adolescents aged 19-15 years old as follows: 
From the statistic of reproductive condition, the birth rate in adolescents aged 19- 15 years old calculated from the number of births per 1, 000population in 2014in Tak Province, Rayong Province, Chonburi Province, Nakhon Nayok Province, Samutsakorn Province, and Prachuabkirikan Province, the birth rate in adolescents aged 19- 15 years old is up to 74.9-60percent. This is indicated that there are increasing numbers of teenage moms in the society of Thailand.

\section{Birth rate}

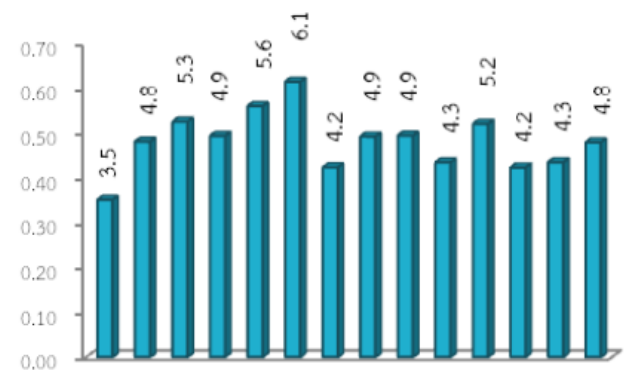

$123456789101112 \mathrm{BKK}$

Area

Fig. 1. Birth rate in adolescents aged 15-19 years old per thousand of female population aged 15-19 years old: in 2014 . Source: Bureau of Reproductive Health.

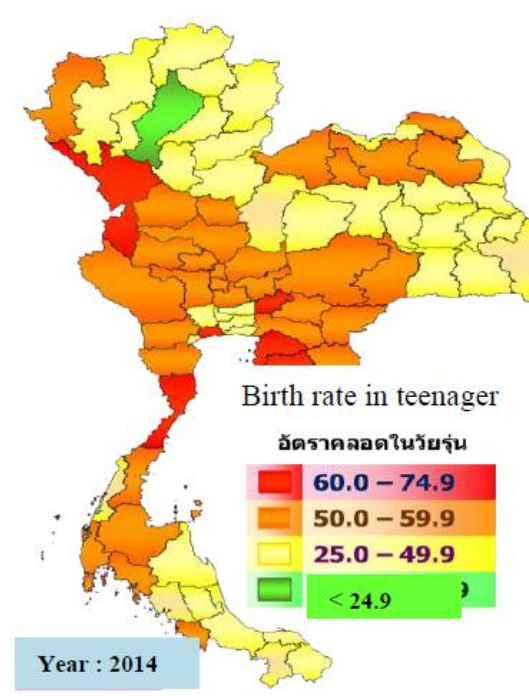

Fig. 2. Birth rate in adolescents aged 15-19 years old per thousand of female population.

Source: Bureau of Reproductive Health.

As per Section 1454, including Section 1436, if minors who want to get married are at the age of seventeen years old but less than twenty years old, they shall be permitted by the consent of their parents in case that they have both father and mother, have consent of either father or mother. However, in case that his or her father or mother died, or a father or a mother is in condition of state of being unable to give consent, or a father or a mother is under the circumstances that make the minor unable to ask for such consent, minor's adopter, in case the minor is and adopted child; his or her guardian, in case there is no person giving consent, a betrothal concluded by the minor without the said consent is voidable. But if there are any apporpriate reasons, and the court may allow the coupleto marry before attainingseventeen years old without asking for consent from parents [4]. Even though there is a person under eighteen years of age who committed an offense by having sexual intercourse on child over the age of thirteen but not exceed fifteen years old have consent [5], it is counted as the guilty about sex by law. However, such provision does not eliminate the relationship in Civil Law [5], so it is counted that the marriage shall be deemed to be valid from the time it was made. The minors have become sui juris since then. In Section 20, it can be seen from the society today that there are increasing numbers of minors who are cohabiting together as husband and wife for both legally and illegally. This problem will lead them to have premature pregnancy and become teenage moms who have to be responsible to raise their children, lack of educational opportunities, and it affects the development of the country's population.

With the above reasons, the researcher has seen that the cohabitation as husband and wife is a major matter. Hence, to study on both legal and illegal cohabitation as husband and wife of minors affecting the quality of life shall be made to have correct understanding on the law enforcement that will be helpful to protect the rights and promote the quality of life of minors.

\section{MEthodology}

\section{A. Objective of the Research}

To study about the cohabitation as husband and wife of minors as per the Civil and Commercial Code.

\section{B. Research Methodology}

A study on cohabitation as husband and wife of minors affecting the quality of life is the research conducted to obtain correct understanding of the law enforcement in order to apply appropriate legal measures by using qualitative research. The documentary research is applied by studying and collection documents and data related to the marriage under the Civil and Commercial Code as well as Sexual Offenses according to the criminal law of Thailand. Then, it is analyzed on cohabitation as husband and wife to find appropriate measures.

\section{Expected Benefits}

1) To use as a guidance to create measures to enforce minors who cohabit as husband and wife by violating conditions of marriage for both marriage while underage or marriage without the consent of father and mother, adopters, or parents.

2) For the benefits of law education and being the guidelines for the improvement and development of family law in order to guarantee and protect the rights of minors that will lead to the improvement of quality of life for population.

\section{Literature Review}

\section{1) The definition of "minor"}

"Minor"meansthe natural person who is under the legal age. Therefore, the minor begins as being a personality with the full completion of birth as a living child. Minor may reach the legal age by 2 causes which are:

1) A person at the age of twenty years old ceases from being a minor and becomes sui juriswhen such minor reaches the legal age by using criteria of personality 
counted from the date of birth as per the Civil and Commercial Code Section 1972.

2) The minor will become sui juris by marriage if it is made as per Section. 1448 which is counted as reaching the legal age by marriage as per the Civil and Commercial Code Section.20

\section{2) Marriage conditions}

Marriage is a civil contract that gives social status and family status. Thailand has set several conditions of marriage. The law requires that a marriage can take place only when the man and woman have completed their seventeenth year of age. But the Court may, in case of having appropriate reason, allow them to marry before attaining such age as per Section

.1448Such condition is not a fixed condition, but it varies according to the social conditions [6] .If there is a breach of the conditions of marriage because the age is under seventeen years old, the marriage is voidable as per Section .1503 Parents who are stakeholders may request the court to revoke the marriage as per Section 1504, but it must be carried out before the man and the woman reach the age of seventeen years old or before the woman got pregnant, or else, such voidable marriage shall be deemed to be valid from the time it was made as per Section 1504, paragraph two.

In the case of the criminal offense where defendant no. 1 had sexual intercourse with the victim who is under the age of 15 years old with the consent of the victim, it is counted as an offense under Criminal Code Section 277, first paragraph. For the last paragraph, it is stated that the offender who is the man commiting against the girl over thirteen years old, but not yet over fifteen years old with her consent, and the court allows the man and the girl to marry together afterwards, the offender shall not be punished for such offence he had made [7]. It means that in the case that boy and girl are under the age of 17 years old, they cannot be married, unless, the Court may allow them to marry before attaining such age as per the Civil and Commercial Code Section. 1448 Hence, the man shall not be punished for such offence. But, if the defendant no. 1 and the victim reach the age of 17 years old, they can marry without the consent from the court, and it is counted that the defendant no. 1and the victim are husband and wife by law. The defendant no. 1shall not be punished [8].During such situation, Miss M. does not reach the age of 17 years old, so she cannot enter into the marriage; unless, the Court may allow them to marry before attaining such age as per the Civil and Commercial Code Section .1448In the case that the defendant would like to cohabit as husband and wife with Miss M, but the action that Mrs. J, mother of Miss M., filed the complaint to the Central Juvenile and Family Court to ask permission for Miss $M$ to register for marriage with the defendant occurred after the criminal situation. Even though the Central Juvenile and Family Court allowed as per the complaint, the offense of the defendant cannot be eliminated. Therefore, the judgment provided from the Subordinate Court is counted as legitimacy. However, after the Central Juvenile and Family Court allowed the defendant and Miss M to enter into marriage, the action of the defendant on having sexual intercourse with a girl not yet over fifteen years of age and not being his own wife as per Section 277, first paragraph, is not deemed to be punished as it is mentioned in the last paragraph. Although the defendant does not perform a petition to the Supreme Court, such problem is the law related to the peace, so the Supreme Court has the power to perform self-diagnosis.

In addition to the age and gender of the person, a marriage cannot take place if either the man or the woman is an insane person or adjudged incompetent. If there is a breach of the conditions of marriage by marrying someone insane or incompetent, the marriage is void as per Section .1495In this case, a stakeholder can request a court to judge that such marriage is void, so it deems as there is no marriage occurred. A marriage cannot take place if the man and woman are blood relations in the direct ascendant such as father, mother, grandparents, and great grandparents, or descendants such as between daughter and son, grandchildren, and great grandchildren, brother or sister of full or half blood. The mentioned relationship shall be in accordance with blood relation without regard to its legitimacy. The breach of the prohibition of marriage will be counted as void as per Section .1495The marriage couple shall not be an adopter and foster. The law requires the adopter to be parents and the foster is the legal child of the adopter. However, the adoption will become dissolved if the marriage is made in contravention as per Section 32/1598, but the marriage is not void.

According to family law in the past, one man may have several wives, but the current law is produced with the purpose of marriage between one male and one female. Therefore, the marriage cannot take place if the man or woman is already the spouse of another person. The Supreme Court Judgment Number 2547/6365indicated that while the defendant entered into marriage registration with lieutenant $S$. on May 3, 1982, the lieutenant S had already registered with Mrs. S before. Therefore, the marriage between the defendant and the lieutenant $\mathrm{S}$ violated the Civil and Commercial Code, Section 1452, so it is void as per the Civil and Commercial Code, Section) 1496previous). Such void was counted as the defendant and lieutenant $S$ did not marry each other, so they could not provide ratification. Even though lieutenant $S$ entered into the registration of divorce with Mrs. S. on October 30, 1992, the marriage registration between the defendant and the lieutenant $\mathrm{S}$ could not be valid. In case of the woman whose husband died or whose marriage has become terminated, the woman can enter into marriage again after it exceeds three hundred and ten days counted from the termination of her previous marriage, unless; a child was born during that periodor the divorced couple remarry; there is a certificate issued by a qualified doctor who is a lawful physical practitioner in medicine showing that the woman is not pregnant, or there is an order of the Court allowing the woman to marry.

When a marriage is one type of a contract, man and woman who have intention to enter into marriage contract shall provide consent to become husband and wife and disclose by the presence of the registrar. The registrar shall record such consent at the time s well. In the case of minors with the seventeenth of age, they shall be permitted to enter into marriage by the consent of parents, father or mother, adopter, or guardian depending on each case. The marriage without the consent is voidable. Moreover, the marriage under this Code shall be affected only on registration being made as per Section 1457to the registrar. The objective determined to register for marriage as per the Form of Marriage is to make it 
in common by providing marriage certificate which is counted as a public document with legal action to the spouse, the third party, and the state [9] as per the Supreme Court Judgment Number 2545/2510according to Family Law Act, Section 6, paragraph two. The spouses shall sign by the presence of the registrar and two witnesses who have to sign their names at that time. If there is only a signature of one witness only, it is counted as not to sign in the presence of two witnesses, so it means that the marriage did not comply with the procedures of law legally, so the marriage is not valid under the law.

\section{RESULT AND DISCUSSION}

By law, Section 1448 stipulates "Section 1448. A marriage can take place only when the man and woman have completed their seventeenth year of age. But the Court may, in case of having appropriate reason, allow them to marry before attaining such age." However, it can be seen that it is not in the strict order because even though minors violate the terms of the marriage condition as they are under seventeen years old, and it is not the case that the court allow to marry, the voidable marriage which the court did not order as the cancellation of the marriage until man and woman reach the age of seventeen or if the woman is pregnant before the age of seventeen shall be counted as a valid marriage from the time that it was made.

While the marriage of minors is done without the consent of their parents, father or mother, adopter, or guardian, it is counted as voidable. However, the right to request cancellation of the marriage shall be canceled when spouses reach twentieth years of age or when the woman is pregnant as well. The right to request cancellation of the marriage shall be valid for one year counted from marriage notified date. If there is a cohabitation of minors as husband and wife without marriage registration, even though they received the consent from parents, adopter, or guardian, the minors are not considered as becoming sui juris from marriage because legal marriage is made only by registration. Meanwhile, the marriage that violates both conditions has no provision required as a criminal offense. Therefore, the state cannot use the criminal sanction to punish those who violated conditions.

\section{DISCUSSION}

Since there is no law to force minors who violate conditions of marriage by cohabiting as husband and wife in the case of underage or entering into marriage without the consent of parents, adopter, or guardian, including cohabiting as husband and wife without register for the marriage certificate. If this case is considered as an offender who is under eighteenth years of age committed the offense by having sexual intercourse with a child over thirteenth years of age but not more than fifteenth years of age even the child agrees to do so, even the law aims to punish by using criminal law, it is exempted if the court allowed the parties to marry after that. In this case, the offender will not be liable for such action. If the offender is prosecuted for an offense, he shall be released. This presented that the law aims to protect and give importance to marriage in order to build family institution rather than punishing those who violate the law in order not to commit crime.

\section{CONCLUSION}

From the research it was conclude that a marriage can take place only when the man and woman have completed their seventeenth year of age, according to the law of Thailand. But the Court may, in case of having appropriate reason, allow them to marry before attaining such age. However, the marriage is counted as voidable marriage if minors enter into marriage without permission. If the court has seen that it isappropriated, minors may be allowed to marry even they are not attaining seventeen years old. However, in the case that the applicant is a person under eighteen years old, and such applicant has had sexual intercourse on child over thirteen years old but not exceed fifteen years old with assent, the offender will not be punished. On the other hand, if the court has not order to cancel the marriage until man and woman reach the age of seventeen, or if the woman is being pregnant, the marriage is counted as a valid marriage from the time that it was made.

\section{RECOMMENDATIONS}

There should be a study on cohabitation as husband and wife of minors in another country to compare the similarities and differences between Thailand and other countries, especially in ASEAN countries, including the conditions caused by a criminal violation of the conditions of marriage.

\section{ACKNOWLEDGMENT}

This research was supported by the Research and Development Institute, Suan Sunandha Rajabhat University, Thailand.

\section{REFERENCES}

[1] W. Suridechakul, "Factors affecting sustainable community development: A case study of dusit district community," presented at the EEED 2015, Zakynthos Island, Greece, July 16-20, 2015.

[2] K. Yoowattana, "The study of ground of divorce under the civil and commercial code that affects quality of life," J. International Journal of Systems Applications, Engineering and Development, 2016, pp. 1-4.

[3] P. Kampusiri, The Description of the Civil and Commercial Code, Book 5 Family Law, Bangkok.: Thammasat University, 2013.

[4] Civil and Commercial Code, 2014.

[5] P. Bundet, The Description of the Civil and Commercial Code, Book 5 Family Law, Bangkok.: Institute of Legal Education of the Thai Bar, 2010, pp. 148.

[6] S. Thikha-utamakorn, The Civil and Commercial Code Book 5, Family Law. Complete Version, Bangkok, Thailand.: Pholsiam Printing Publishing, 2011.

[7] Criminal Code, 2013.

[8] S. Akkarawiboon, The Description of the Civil and Commercial Code, Book 5. Family Law. Bangkok.: Winyuchon Publishing Co., Ltd, 2009.

[9] Supreme Court Judgement.

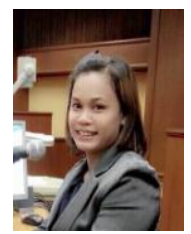

Kamonwan Yoowattana was born on January 16, 1979 She has completed her bachelor and master degree in law. She is a lecturer with Faculty of Humanities and Social Sciences, Suan Sunandha Rajabhat University, Thailand. Her interest is in family law and political. 